\title{
Accounting
}

\section{The effect of corporate governance characteristics on the performance of Jordanian banks}

\author{
Lina Warrad ${ }^{\mathrm{a} *}$ and Laith Khaddam ${ }^{\mathrm{a}}$
}

${ }^{a}$ Applied Science Private University, Jordan

\begin{tabular}{l}
\hline C H R O N I C L E \\
\hline Article history: \\
Received October 292019 \\
Received in revised format \\
November 212019 \\
Accepted November 292019 \\
Available online \\
December 22019 \\
\hline Keywords: \\
Corporate governance \\
Return on Equity \\
Amman Stock Exchange (ASE)
\end{tabular}

\section{A B S T R A C T}

\begin{abstract}
Corporate governance has become a common discussion issue in developed and developing countries. Therefore, the intensive interest that the corporate governance determines firm performance and protects the interests of shareholders has result in increasing global concern about the corporate governance concept and determinants. There is an increasing forms of corporate finance literature which build a correlation between corporate governance techniques and financial performance. This study represents a new attempt to show the role of corporate governance characteristics on the performance of Jordanian Banks expressed by return on equity ROE during the period from 2014 to 2017. The investigation employed statistics measurements and tools to state the relationships between ROE and different variables. The study indicates a significant effects of different corporate governance characteristics on the performance of banks. In other words, the study reports significant effects of the board size, board diligence, audit committee size and audit committee diligence separately on ROE by considering two controlling variables; namely, firm size and return on assets.
\end{abstract}

\section{Introduction}

\subsection{Agency Theory}

Agency theory has become the backbone of corporate governance. It is the premier theory to express corporate governance. Agency theory defines the conflicts of interests between the shareholders and managers due to conflicts of interest between managers and owners, agency costs may increase. Modernistic corporate governance principles back an approach that considerate and balances the legal and plausible needs, interests, and expectations of its stakeholders in a comprehensive, ethical, and sustainable manner as part of its decision-making (Dzingai \& Fakoya, 2017). Agency theory supposes the main friction is the conflict of interests between the different parties interested in the company. An agency problem exists if a principal, such as the shareholder, use an agent, such as the CEO and his/her executive team, to drive the company. Agency theory assumes that managers and shareholders are expected to have potentially conflicting interests (https://www2.deloitte.com).

\subsection{Corporate Governance Guidance in Jordanian Banks}

The OECD has defined institutional governance as a set of relationships between the management of the institution, its governing board, its shareholders and other stakeholders of interest to the institution, as well as the mechanism by which it clarifies the objectives of the institution and the means to achieve and monitor their achievement. Thus, good institutional governance provides both executive boards and management with appropriate incentives to reach the goals that are in the interest of the organization, and facilitates the creation of an effective monitoring process, thus helping the organization exploit its resources * Corresponding author. Tel.: +9626746888

E-mail address: 1_warrad@asu.edu.jo (L. Warrad) 
efficiently. In preparing the corporate governance guide, each bank must express in its own language its own view of institutional governance in terms of its meaning and importance, and the following paragraph provides an example of what the guide's introduction might include:

The Bank's institutional governance is a key to the future development and institutional performance of HBTF's activities as a recipient of deposit and equity funds, and to enable it to contribute successfully to the development of the Jordanian banking system, thus enhancing the efficiency of the national economy. Accordingly, the Board of Directors decided to adopt the corporate governance guide (hereinafter referred to as the Manual) in accordance with both the Jordanian Central Bank's instructions and international best practices. The Guide is based on the following four guiding principles:

- Equality in the treatment of all stakeholders (e.g. shareholders, depositors, creditors, bank employees, regulatory authorities).

- Transparency and disclosure, in a way that enables relevant entities to assess the status and financial performance of the Bank.

- Accountability in the relationship between the Executive Bank's management and the Board of Directors, the Board of Directors and shareholders, and the Board of Directors and other relevant stakeholders.

- Responsibility, in terms of clear separation of responsibilities and delegation of authority". (www.abj.org.jo).

\subsection{Corporate Governance and performance}

According to theory, perfect governance indicates to a combination of structures and techniques that stand in the interests of all parties participated (agency theory) and which ensures the thought of stakeholders is understood and information is provided fairly (stakeholder theory). Its structures and techniques are needed to impose all parties to work together towards a common goal (stewardship theory). It has investigated which governance characteristics have a scientifically confirmed association with corporate performance to help boards and directors decide on the right structures and techniques. Many of empirical studies revealed a positive association between governance characteristics and corporate performance, measured in both financial metrics as well as non-financial metrics. In tune with the agency theory, the board of directors assumes a controlling function that matches the interests of managers with the interest of the shareholders (https://www2.deloitte.com). The current paper will try to investigate that various governance measures have a positive effect on the performance of Jordanian Banks

\section{Literature Review}

Corporate governance and its influence on corporate performance is excessively discussed area. In the past decade, empirical research has revealed significant relations between different corporate governance characteristics and corporate performance. Empirical research on corporate governance is based on the theoretical framework of agency theory advanced by Jensen and Meckling (1976), Fama (1980) and Fama and Jensen (1983). Agency theory points that a better-governed firm should have better performance and higher valuation due to lower agency costs. This prediction is supported by many studies (Azeez, 2015). Al-ahdal et al. (2020) studied some firms in India on the relationship between corporate governance and financial performance and showed the effect of corporate governance techniques on the financial performance of Indian and GCC listed firms. The study concluded that board accountability and audit committee had an insignificant effect on firms' performance measured by return on equities and Tobin's Q. Similarly, transparency and disclosure (TD) had an insignificant negative effect on firms' performance measured by Tobin's Q. Also, the country dummy results revealed that Indian firms were performing better than Gulf countries in terms of corporate governance practices and financial performance.

Naciti (2019) performed an investigation on corporate governance and the firm's performance by proving that the composition of the board of directors impacts the firm's sustainability performance, through developed hypotheses depending on the agency theory and stakeholder theory to assess the impact on social and environmental sustainability elements. The results concluded that firms with more diversity on the board and a separation between chair and CEO roles had higher sustainability performance. Also, findings showed a higher number of independent directors' command to lower sustainability performance. Bhagat and Bolton (2019) revealed that director's stock ownership most systematically and positively correlated with future corporate performance across different specifications, estimation mechanisms, and for different sub-samples. One specific sub-sample of major public interest is the 100 largest U.S. financial institutions around 2008. Bank director stock ownership was positively correlated with future bank performance, and bank director stock ownership was negatively correlated with future bank risk, both prior to and during the financial crisis - both results of major interest to senior bank regulators. Moreover, Brogi and Lagasio (2019) showed a significant and positive correlation between ESG and that the environmental consciousness in banks was strongly correlated to profitability, supplying collaborations for policy makers and policy takers. ESG and that the environmental awareness in banks is strongly related to profitability, providing implications for policy makers and policy takers. Naciti et al. (2019) tried to investigate the relationship between the application of good corporate governance exercises in 
association with the economic value of listed banks in an emerging market such as the Lima Stock Exchange, considering the increasing importance of corporate governance, and in the nonattendance of empirical evidence on banks in emerging markets. The methodology applied used a model that evaluates the Tobin's Q, leverage ratios, portfolio quality, efficiency and return on assets (ROA) and the dichotomous variable with considering the incorporation into the Good Corporate Governance Index of the stock exchange, Lima, considering a temporality from 2011 to 2016.

Chua et al. (2018) reported that board independence and board rewards had positively affected firm performance respectively to ROA and TQ. However, board gender diversity was negatively correlated with ROA. These results behold that higher number of board independence and higher amount of board rewards could improve firm performance. Though the Malaysian Code of corporate governance, the importance of having more females on board with the quota of $30 \%$ has been underline with the result clearly discussed that many female representations on the board may not improve but decline firm performance. Also, Saidat et al. (2018) showed that board size both in terms of Tobin's Q and return on assets ROA had negative associations with the performance of family firms. In non-family firms, there was no organized association with corporate performance. There is a strong association between corporate performance and independent directors in non-family firms. Moreover, the authors showed some evidence for association between performance and independent directors in family firms. Also, results revealed that ownership concentration has an insignificant relationship with corporate performance and in family firms had a negative and significant relationship with Tobin's Q. There is a significant correlation between local investors' ownership and corporate performance as measured by Tobin's Q in family and non-family firms.

Khatab et al. (2011) tried to investigate the relationship between corporate governance and firm's performance of 20 firms listed at Karachi Stock Exchange. The performance of corporate governance was expressed by Tobin's Q, while the performance of the firms was expressed by return on assets (ROA) and return on equity (ROE). The result revealed that leverage and growth had positive relationships with Tobin's Q, which means a significant impact in measuring performance of the firm. It means that firms with having good corporate governance measures doing well as compared to the firms having no or less corporate governance pursuit

\section{Methodology}

\subsection{Study Population, Study Sample and period}

The study population consisted of all Jordanian banks listed on the Amman Stock Exchange where 11 out of the 13 banks were analyzed. Arab Islamic International Bank was excluded due to the absence of annual reports during the study period from 2015 to 2018, and Capital Bank was excluded from the study sample due to insufficient governance information in the annual report. Descriptive analysis and correlation coefficient as well as simple and multiple regressions were used to infer the correlation between the characteristics of corporate governance and the performance of Jordanian banks.

\subsection{Independent Variables}

ROE: is applied to measure the return on the shareholders' equity and the firms' efficiency at generating profits. It can be counted by divided profit after tax by total equity shares at the end of the year (Al-ahdal et al., 2020).

\subsection{Dependent Variable}

BORSIZE: Many researchers debate that firms' performance vary according to the size of board of directors. When the number of directors on the board is big, firms would gain more arrive to many resources in comparison to the case when board size is small. The bigger board of directors, the more skilled, practiced and knowledgeable people be ready which could result in more accurate learning, decision making process and eventually preferable firm performance (Yameen, et al., 2019).

BORDEL: Board of directors' diligence is expressed by the number of board meeting; the recurrence of meetings is the time devoted for controlling management. It was concluded that when board members meet more repeatedly, the performance becomes better as a result. Board meetings are very fundamental for directors as they utilize the attendance as a way which enables them to control properly (Yameen, et al., 2019).

ACSIZE: Audit committee is one of the essential elements that occupied an important position in reinforcement firms' performance, it provides a sufficient safety against fraud and makes sure that these securities are in related with the best practices. Audit committee members must be qualified holders and have the experience in the field of auditing. Small audit committee size that consists of well-experienced members and financial expertise connect positively with firms' performance (Yameen, et al., 2019). 
ACDEL: Audit committee diligence pointing to the number of committee meetings that are convene yearly. Some studies debate that repeatedly meetings of audit committee may decrease the number of financial reporting troubles. Audit committee diligence appears to audit members' willingness to work together and maintain an elevated level of activity as they have to compact with the external and internal auditors, management and other related parties. If audit committee meetings are held repeatedly, the committee would be conscious and then they will draw the auditors' attention on the auditing cases that require awareness and caution (Yameen, et al., 2019).

\subsection{Control variables}

COMSIZE: This variable has been utilized in many previous studies (e.g. Cassar and Holmes, 2003). It was discussed that the company size variable was probable to have a positive relationship with corporate performance. whereas large companies are probable to have more opportunity than smaller companies according to accessing external fund at less cost and increase company value, due to their size. On the other hand, many studies such as (Agrawal and Knoeber, 1996) discussed that small companies are better than large firms because of growth opportunities. The reason for that is because the small companies are probable to respond with a tough corporate governance rules in order to a catch investor, and thus more external funds to invest these opportunities and increase profitability (Saidat et al., 2018).

ROA: A measure of how profitable a firm is related to its total assets. ROA provides with a vision as to how efficient management is at utilizing its assets to generate profit. ROA is calculated by dividing a firm's annual profit by its total assets.

\subsection{Study Hypotheses}

Main Hypothesis

$\mathrm{H}_{1}$ : There is a significant effect of corporate governance characteristics on Jordanian Banks' return on equity.

\section{Sub Hypotheses}

$\mathrm{H}_{11}$ : There is a significant effect of board size on Jordanian Banks' return on equity.

$\mathrm{H}_{12}$ : There is a significant effect of board diligence on Jordanian Banks' return on equity.

$\mathrm{H}_{13}$ : There is a significant effect of audit committee size on Jordanian Banks' return on equity.

$\mathrm{H}_{14}$ : There is asignificant effect of audit committee diligence on Jordanian Banks' return on equity.

\subsection{Study model}

$\mathrm{ROE}=\beta_{0}+\beta_{1} \mathrm{BORSIZE}_{\mathrm{it}}+\beta_{2} \mathrm{BORDEL}_{\mathrm{it}}+\beta_{3} \mathrm{ACSIZE}_{\mathrm{it}}+\beta_{4} \mathrm{ACDEL}_{\mathrm{it}}+\beta_{5} \mathrm{COMSIZE}_{\mathrm{it}}+\beta_{6} \mathrm{ROA}+\varepsilon$

where $\beta_{i}, i=0, \ldots, 6$ represent the coefficients and $\varepsilon$ denotes the residuals. Table 1 shows some basic statistics on collected data.

Table 1

Descriptive Analysis

\begin{tabular}{|c|c|c|c|c|c|}
\hline Variable & Observations & Mean & Standard Deviation & Minimum & Maximum \\
\hline BORSIZE & 44 & 11.68182 & .9091966 & 9 & 13 \\
\hline BORDEL & 44 & 8.045455 & 3.011254 & 6 & 19 \\
\hline ACSIZE & 44 & 4.113636 & 1.242951 & 3 & 7 \\
\hline ACDEL & 44 & 7.068182 & 2.920638 & 4 & 16 \\
\hline ROE & 44 & 8.852045 & 3.25294 & 2.07 & 15.76 \\
\hline COMSIZE & 44 & 1.090045 & .4537032 & .092 & 1.82 \\
\hline ROA & 44 & 9.472045 & .3773807 & 9.012 & 10.413 \\
\hline
\end{tabular}

The analyses were parted into seven parts which are board-size, board diligence, audit committee size, audit committee diligence, return on equity, company size and return on assets. Table 1 exhibits that there is a substance zone of divergence between the chosen samples of this study. The extent of board size BORSIZE is from 9 to 13 with a mean of 11.68182 and a standard deviation of .9091966. The extent of the board diligence BORDEL is from 6 to 19 with a mean of 8.045455 and std. of 3.011254. Also, for audit committee size ACSIZE is from 3 to 7, with a mean of 4.113636, and std. of 1.242951 and the extent of audit committee diligence ACDEL are from 4 to 16, with a mean of 7.068182 and a std. of 3.25294. Finally, the return on equity ROE extends from 2.07 to 15.76 , with a mean of 8.852045 and a std. of 3.25294 . Given the control variables, the extent of company size COMSIZE is from .092 to 1.82 , with mean of 1.090045 and a std. of 4537032 , and return on assets ROA is from 9.012 to 10.413 with a mean of 9.472045 and a std. of .3773807 . Table 2 shows the results of Pearson correlation coefficients. 
Table 2

Pearson's Correlation Coefficient

\begin{tabular}{|c|c|c|c|c|c|c|c|}
\hline Variables & BORSIZE & BORDE & ACSIZE & ACDEL & ROE & COMSIZE & $\mathrm{ROA}$ \\
\hline BORSIZE & 1.0000 & & & & & & \\
\hline BORDEL & -0.0116 & 1.0000 & & & & & \\
\hline ACSIZE & -0.1113 & 0.1229 & 1.0000 & & & & \\
\hline ACDEL & 0.1748 & 0.8643 & -0.1303 & 1.0000 & & & \\
\hline ROE & -0.1301 & -0.2795 & -0.1821 & -0.3314 & 1.0000 & & \\
\hline COMSIZE & 0.3561 & -0.3137 & -0.2266 & -0.1455 & 0.1161 & 1.0000 & \\
\hline ROA & -0.1368 & -0.4321 & -0.0635 & -0.4099 & 0.7700 & 0.1570 & 1.0000 \\
\hline
\end{tabular}

Correlation analysis was performed in order to arrive at the degree of correlation between study variables that are between +1 and -1. Looking at Table 2, we can conclude that there was a strong relationship between some variables with a positive signal, which means that the positive relationship between these variables existed, on the other hand, there is a weak relationship between some other variables, and either this trend is positive or negative. Fig. 1 demonstrates the results of Pearson covariance coefficients. Variance means how the mean values of two variables move together. If one variable moves up whenever the other variable moves up and the same relationship appears when one of the variables decreases, these variables are described as having positive variation. As shown above, some variables have a positive variation, while the remaining variables have a negative variation, which means moving in the opposite direction.

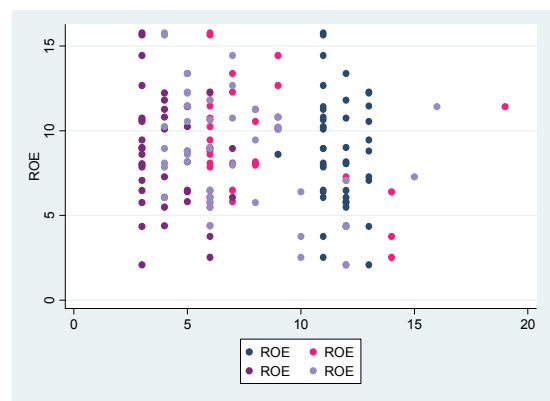

Fig. 1. The results of Pearson correlation between ROEs

\subsection{Hypotheses testing}

\subsubsection{The first hypothesis}

The first hypothesis of this survey investigates the relationship between corporate governance and return on equities of Jordanian banks. Table 3 shows the results. A closer look at the previous readings in Table 1 shows that R-squared 0.6638 is higher than 0.60 , which indicates that the data for this relationship is largely correlated, as well as those 0.6638 percent differences in return on equity ROE across two control variables. The size of the company COMSIZE, and the return on assets ROA, can be explained by the characteristics of corporate governance. Thus, the remaining percentage of differences in return on equity ROE can be explained by other variables other than the characteristics of corporate governance.

Table 3

The results of ANOVA test and regression analysis

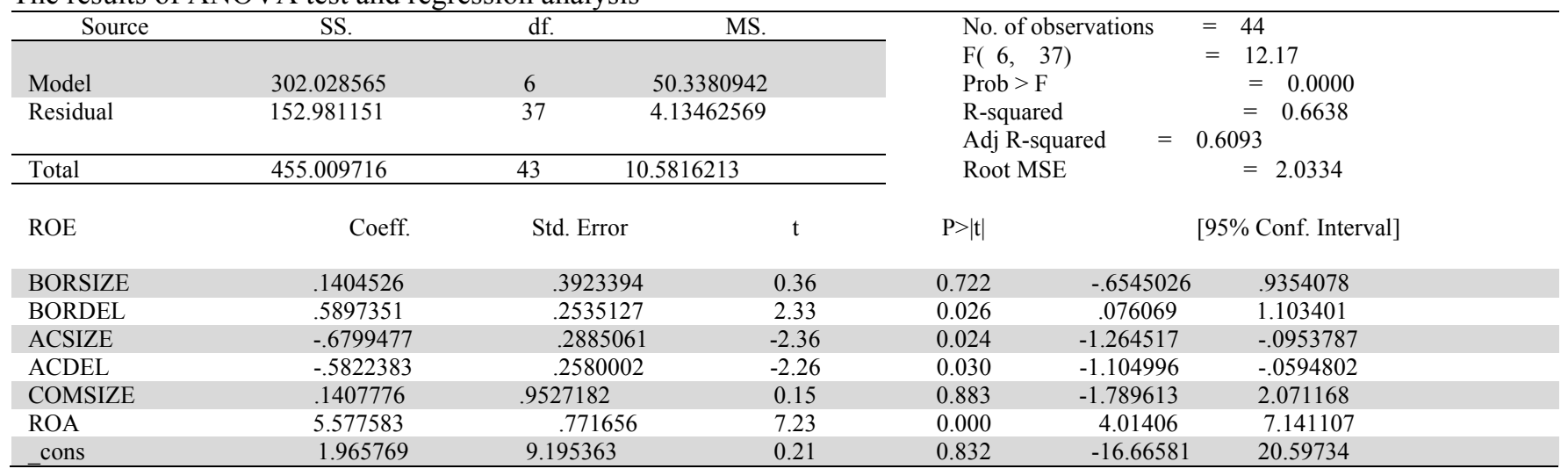


By analyzing the probability value of the corporate governance characteristics of 0.0000 below 0.05 , it was concluded that by adjusting the relationship with the company size COMSIZE and return on assets ROA variables, the characteristics of corporate governance together are substantive variables to explain the return on equity ROE, and therefore the hypothesis is confirmed that the characteristics of corporate governance were highly correlated with Jordanian Banks' performance by controlling the relationship with COMSIZE and ROA. The result of analysis of the main hypothesis shows that the result of the analysis is in agreement with most of the previous studies presented in this paper in terms of the positive impact of the characteristics of corporate governance on the performance of companies.

\subsubsection{The second hypothesis}

The second hypothesis of this paper investigates the effect of board size on return on equites of Jordanian Banks. Fig. 2 shows the results of Pearson correlation between board size and return on equities. Table 4 demonstrates the results of ANOVA test and regression analysis.

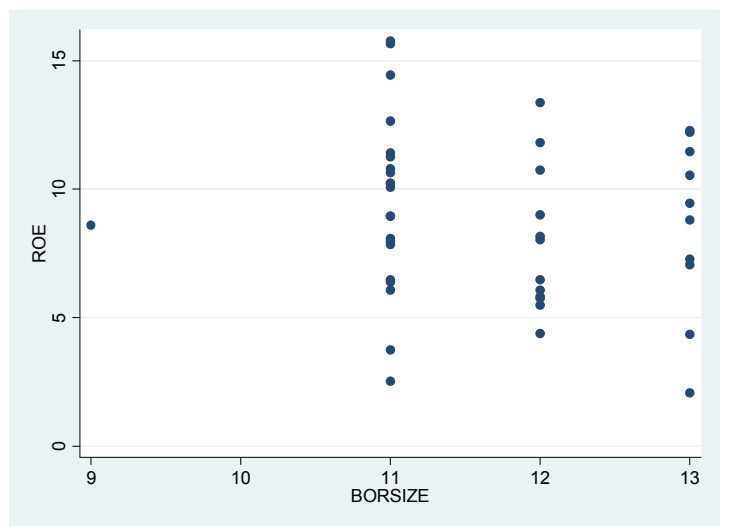

Fig. 2. The results of Pearson correlation test between board size and ROE

Table 4

The results of ANOVA test and regression analysis

\begin{tabular}{|c|c|c|c|c|c|c|}
\hline Source & SS. & df. & MS. & & \multirow{3}{*}{\multicolumn{2}{|c|}{$\begin{array}{llc}\text { No. of observations } & =44 \\
\mathrm{~F}(3,40) & =19.47 \\
\text { Prob }>\mathrm{F} & =0.0000\end{array}$}} \\
\hline & & & & & & \\
\hline Model & 270.087784 & 3 & 90.0292615 & & & \\
\hline Residual & 184.921932 & 40 & 4.62304829 & & R-squared & $=0.5936$ \\
\hline & & & & & Adj R-squared & $=0.5631$ \\
\hline Total & 455.009716 & 43 & 10.5816213 & & Root M & $=2.1501$ \\
\hline ROE & Coeff. & Std. Error & $\mathrm{t}$ & $\mathrm{P}>|\mathrm{t}|$ & \multicolumn{2}{|c|}{ [95\% Conf. Interval] } \\
\hline BORSIZE & -.0981949 & .3946386 & -0.25 & 0.805 & -.8957892 & .6993993 \\
\hline COMSIZE & .0493333 & .9536542 & 0.05 & 0.959 & -1.878074 & 1.97674 \\
\hline ROA & 5.4875 & .7482756 & 7.33 & 0.000 & 3.975179 & 6.999822 \\
\hline cons & 3.550229 & 8.352955 & 0.43 & 0.673 & -13.33172 & 20.43218 \\
\hline
\end{tabular}

A closer look at the previous readings in Table 4 shows that R-squared 0.5936 is to little bit under than 0.60 , which indicates that the data for this relationship is highly correlated, as well as those 0.5936 percent differences in return on equity ROE across two control variables. The size of the company COMSIZE, and the return on assets ROA, can be explained by board size BORSIZE. Thus, the remaining percentage of differences in return on equity ROE can be explained by other variables other than the board size BORSIZE. By analyzing the probability value of the board size BORSIZE of 0.0000 below 0.05 , it was concluded that by adjusting the relationship with the company size COMSIZE and return on assets ROA variables, the board size BORSIZE is a substantive variable to explain the return on equity ROE, and therefore the hypothesis is confirmed and the board size BORSIZE is highly correlated with Jordanian Banks' performance by controlling the relationship with COMSIZE and ROA.

\subsubsection{The third hypothesis}

The third hypothesis of this survey studies the relationship between board diligence and return on equities in Jordanian Banks. Fig. 3 shows the results of Pearson correlation data between two variables. 


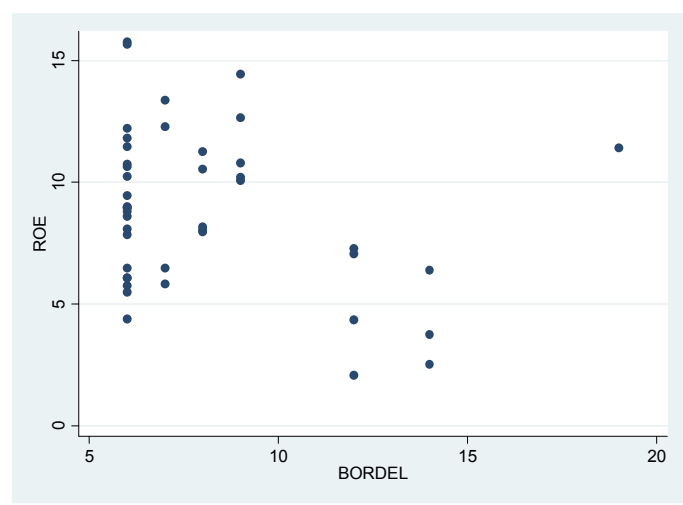

Fig. 3. The Pearson correlation between board diligence and return on equities in Jordanian Banks

Table 5 also presents the results of ANOVA test and regression analysis for testing the third hypothesis.

Table 5

The summary of ANOVA and regression analysis for testing the third hypothesis

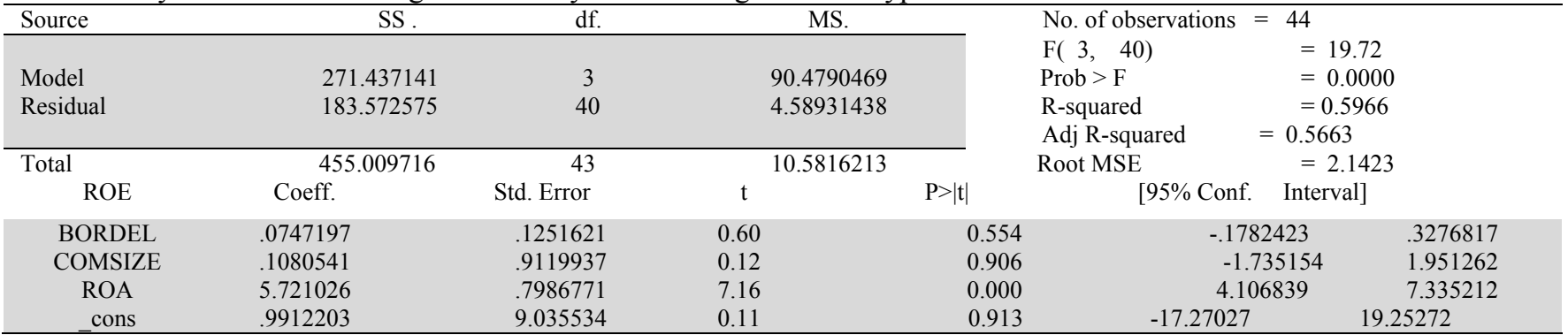

The results of Table 5 indicate that R-squared 0.5966 is to little bit under than 0.60 , which indicates that the data for this relationship is highly correlated, as well as those 0.5966 percent differences in return on equity ROE across two control variables. The size of the company COMSIZE, and the return on assets ROA, can be explained by board diligence BORDEL. Thus, the remaining percentage of differences in return on equity ROE can be explained by other variables other than the board diligence BORDEL.

\subsubsection{The fourth hypothesis}

This hypothesis investigates the relationship between committee size and return on equities of Jordanian Banks. Again, we first present the results of Pearson correlation test between two variables in Fig. 4. By analyzing the probability value of the board diligence BORDEL of 0.0000 below 0.05 , it was concluded that by adjusting the relationship with the company size COMSIZE and return on assets ROA variables, the board diligence BORDEL explain the return on equity ROE, and therefore the hypothesis is confirmed and the board diligence BORDEL was highly correlated with Jordanian Banks' performance by controlling the relationship with COMSIZE and ROA.

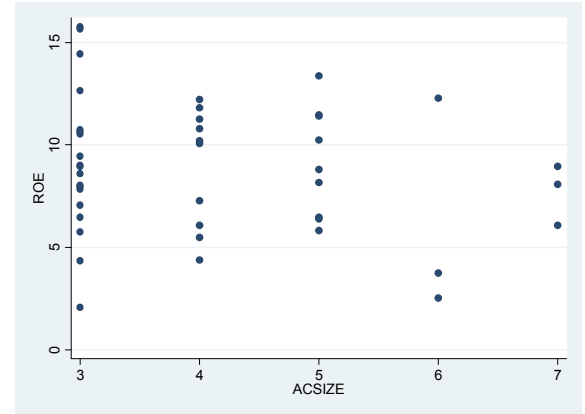

Fig. 4. The results of Pearson correlation between committee size and return on equities of Jordanian Banks 


\section{Table 6}

The summary of testing the fourth hypothesis between committee size and return on equities

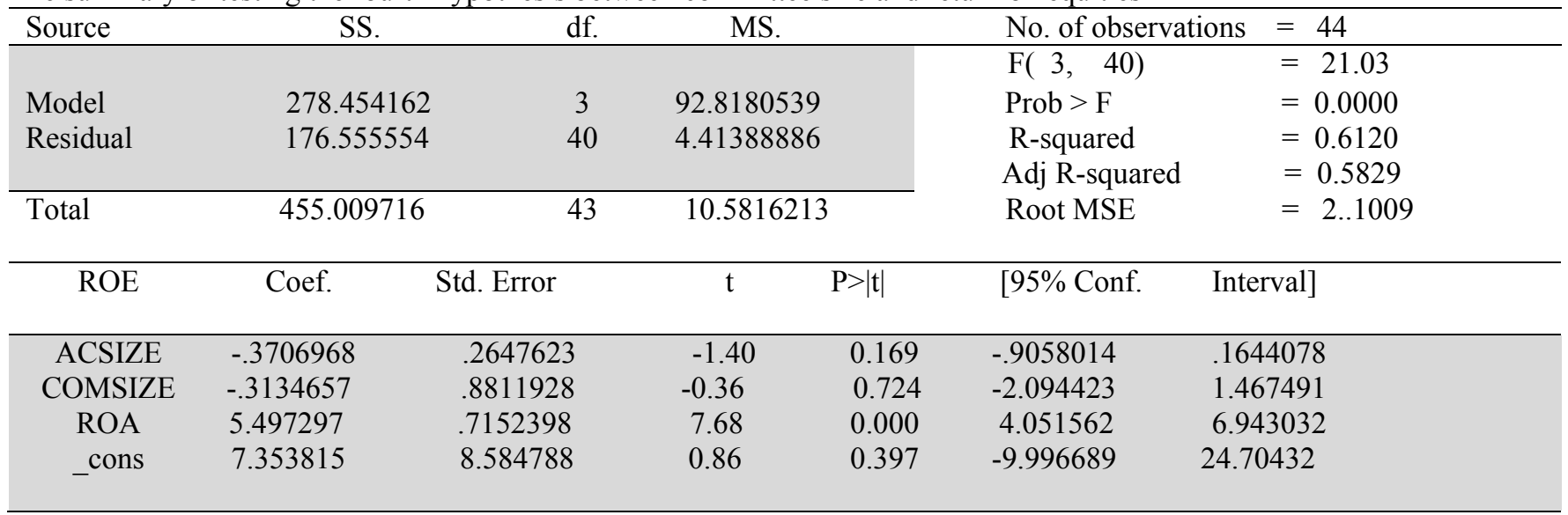

Table 6 shows that R-squared 0.6120 is to little bit higher than 0.60 , which indicates that the data for this relationship is highly correlated, as well as those 0.6120 percent differences in return on equity ROE across two control variables. The size of the company COMSIZE, and the return on assets ROA, can be explained by committee size ACSIZE. Thus, the remaining percentage of differences in return on equity ROE can be explained by other variables other than the committee size ACSIZE.

\subsubsection{The results of testing the fifth hypothesis}

Finally, the last hypothesis of this survey investigates the relationship between audit committee size and return on equities of Jordanian Banks.

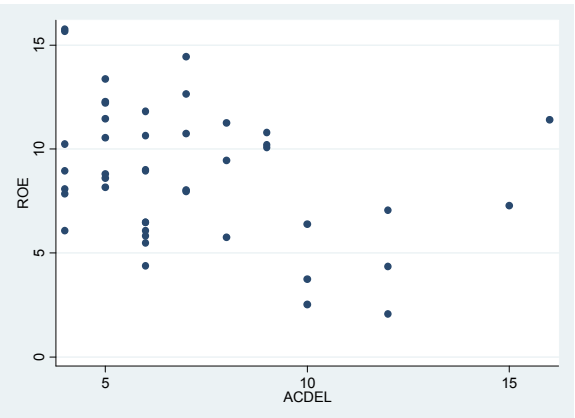

Fig. 5. The results of Pearson correlation between audit committee size and return on equities of Jordanian Banks

By analyzing the probability value of the audit committee size ACSIZE of 0.0000 below 0.05 , it was concluded that by adjusting the relationship with the company size COMSIZE and return on assets ROA variables, the audit committee size ACSIZE is a substantive variable to explain the return on equity ROE, and therefore the hypothesis is confirmed and the audit committee size ACSIZE is highly correlated with Jordanian Banks' performance by controlling the relationship with COMSIZE and ROA.

Table 7

The results of testing the relationship between audit committee diligence and return on equities

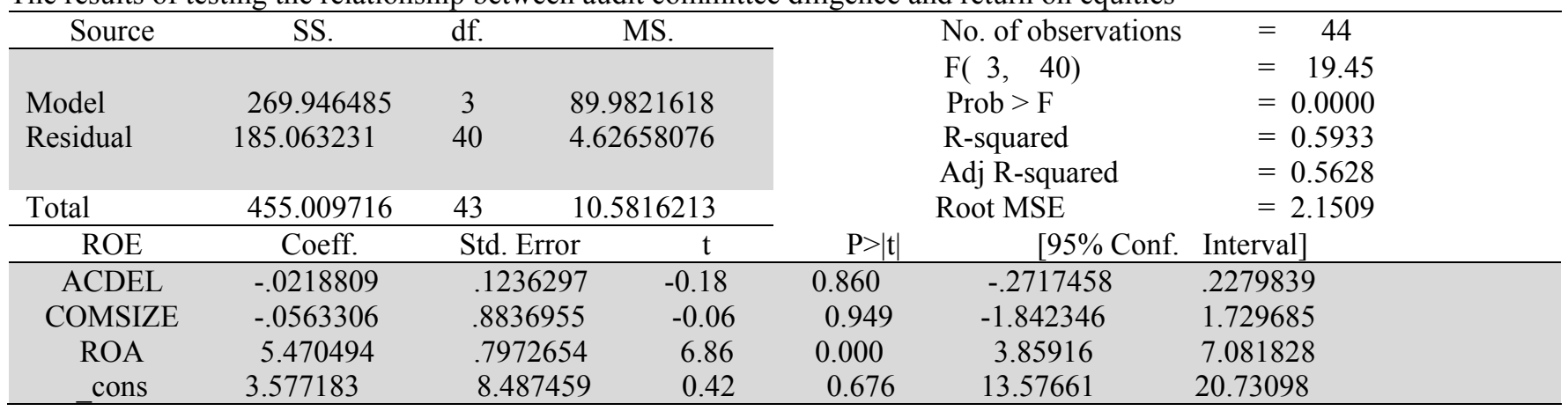


A closer look at the previous readings in Table 7 shows that R-squared 0.5933 is to little bit under than 0.60 , which indicates that the data for this relationship is highly correlated, as well as those 0.5933 percent differences in return on equity ROE across two control variables. The size of the company COMSIZE, and the return on assets ROA, can be explained by sense audit committee diligence ACDEL. Thus, the remaining percentage of differences in return on equity ROE can be explained by other variables other than the sense audit committee diligence ACDEL. By analyzing the probability value of the audit committee diligence ACDEL of 0.0000 below 0.05 , it was concluded that by adjusting the relationship with the company size COMSIZE and return on assets ROA variables, the audit committee diligence ACDEL is a substantive variable to explain the return on equity ROE, and therefore the hypothesis is confirmed and the audit committee diligence ACDEL was highly correlated with Jordanian Banks' performance by controlling the relationship with COMSIZE and ROA.

\section{Results Discussions}

After reading the literature on corporate governance and its characteristics as well as referring to the agency's theory, and doing some research into previous studies on the subject of the current study, we perform the necessary statistical analyzes in order to identify the effects of different factors on bank performance in Jordan. The study generated the following valuable results: There is a substantive effect of the characteristics of corporate governance on the banks' performance measured by return on equity ROE for all the characteristics combined, there is also an substantive effect of each feature individually on the performance; board size, board diligence, audit committee size and audit committee diligence, note that the previous relationships were controlled by the following control variables: company size and return on assets ROA. By analyzing the main hypothesis and sub-hypothesis, the result of analysis of the effect of all the characteristics of the corporate governance, whether combined or individually, is matched by most of the previous studies presented in this research in terms of a positive impact on the performance of the companies.

\section{References}

Al-ahdal, W. M., Alsamhi, M. H., Tabash, M. I., \& Farhan, N. H. (2020). The impact of corporate governance on financial performance of Indian and GCC listed firms: An empirical investigation. Research in International Business and Finance, 51, 101083.

Agrawal, A., \& Knoeber, C. R. (1996). Firm performance and mechanisms to control agency problems between managers and shareholders. Journal of Financial and Quantitative Analysis, 31(3), 377-397.

Azeez, A. A. (2015). Corporate governance and firm performance: evidence from Sri Lanka. Journal of Finance, 3(1), 180-189.

Bhagat, S., \& Bolton, B. (2019). Corporate governance and firm performance: The sequel. Journal of Corporate Finance, 58, 142-168.

Brogi, M., \& Lagasio, V. (2019). Environmental, social, and governance and company profitability: Are financial intermediaries different?. Corporate Social Responsibility and Environmental Management, 26(3), $576-587$.

Cassar, G., \& Holmes, S. (2003). Capital structure and financing of SMEs: Australian evidence. Accounting \& Finance, 43(2), 123-147.

Chua, M. S., Razak, A., \& Hisyam, N. (2018). The Impact of Board of Directors' Characteristics and Remuneration on Companies' Performance in Malaysia. Indian Journal of Public Health Research and Development, 9(11), $1220-1221$.

Dzingai, I., \& Fakoya, M. (2017). Effect of corporate governance structure on the financial performance of Johannesburg Stock Exchange (JSE)-Listed mining firms. Sustainability, 9(6), 867.

Fama, E.F. (1980). Agency problems and the theory of the firm. Journal of Political Economy, 88(2), 288 - 307.

Fama, E. F., \& Jensen, M. C. (1983). Separation of ownership and control. The journal of law and Economics, 26(2), 301-325.

Jensen, M. C., \& Meckling, W. H. (1976). Theory of the firm: Managerial behavior, agency costs and ownership structure. Journal of Financial Economics, 3(4), 305-360.

Klapper, L. F., \& Love, I. (2004). Corporate governance, investor protection, and performance in emerging markets. Journal of Corporate Finance, 10(5), 703-728.

Lizarzaburu, E.R., Burneo, K., Ampuero, G.B., Noriega, L, (2019). Corporate governance in the banking sector of an emerging economy. Journal Globalization, Competitiveness and Governability, 13(1), 79-96.

Naciti, V. (2019). Corporate governance and board of directors: The effect of a board composition on firm sustainability performance. Journal of Cleaner Production, 237, 117727.

Saidat, Z., Silva, M., \& Seaman, C. (2019). The relationship between corporate governance and financial performance: Evidence from Jordanian family and nonfamily firms. Journal of Family Business Management, 9(1), 54-78.

Velnampy, T., \& Pratheepkanth, P. (2013). Corporate governance and firm performance: A study of selected listed companies in Sri Lanka. European Journal of Commerce and Management Research, 2(6), 123-127.

Yameen, M., Farhan, N. H., \& Tabash, M. I. (2019). The impact of corporate governance practices on firm's performance: An empirical evidence from Indian tourism sector. Journal of International Studies, 12(1), 208-228. 
https://www.abj.org.jo/echobusv3.0/systemassets/\%D8\%AF\%D9\%84\%D9\%8A\%D9\%84\%20\%D8\%A7\%D9\%84\%D8\%AD \%D8\%A7\%D9\%83\%D9\%85\%D9\%8A\%D8\%A9.pdf, 7/10/2019, 8:46

https://www2.deloitte.com/content/dam/Deloitte/nl/Documents/risk/deloitte-nl-risk-good-governance-driving-corporateperformance.pdf, 8:20, 9/10/2019

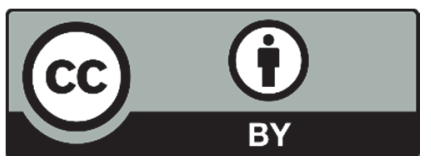

(C) 2019 by the authors; licensee Growing Science, Canada. This is an open access article distributed under the terms and conditions of the Creative Commons Attribution (CC-BY) license (http://creativecommons.org/licenses/by/4.0/). 